\title{
COMPARATIVE BOTANICAL STUDIES ON TWO NEWLY TOMATO GENOTYPES AS AFFECTED BY WASTEWATER AND SHADING: \\ I. MORPHOLOGICAL CHARACTERS. \\ Helali, M.N.; Z.A. Mohammed and I.E. Nofal
}

Agric. Botany Dept., Faculty of Agric., Mansoura Univ. Mansoura, Egypt

ABSTRACT

Two field experiments were carried out at the Agric. Experimental Station, Faculty of Agric., Mansoura University, Egypt during the two growing seasons of 2007-2008 and 2008-2009, aiming to evaluate botanically two newly tomato genotypes grown under shading and wastewater of El-Delta company of fertilizers and Talkha electricity generate mixed with sewage of the vicinity villages, at Dakahlia Governorate, Egypt. The data indicated that Cheyenne (e 448) genotypes recoded an increase in all growth characters studied compared with Gs 12 at different growth stages in both growing seasons. However, in both genotypes, Plant height, numbers of internodes, leaves and branches on the main stem, as well as, fresh and dry weight of the shoot system were increased significantly due to wastewater application at $50 \%$ level whereas decreased insignificantly at $100 \%$ level. Shading agent seemed to have a stimulating effect on different growth characters of the two tomato genotypes under the present investigation compared with the control

The interaction treatments indicated that shading enabled the developing tomato plants to withstand, wastewater at $100 \%$ level.The "S" or sigmoide growth curve was detected in both tomato genotypes studied during the two tomato growing seasons. The highest rate of increase was detected between the 1 st and $2 \underline{\text { nd }}$ sampling date.

Genotype (2) bloomed earlier than genotype (1); by about 7-10 days in the first and second seasons respectively and showed shorter growing period and earlier maturation than genotype.(1). overall all treatments examined. However, irrigation with Wastewater at $50 \%$ level increased whereas shading enlowered the period elapsed from transplanting to flowering in both tomato genotypes. Similarly, wastewater at $100 \%$ level delaying flowering but only with genotype (1) by about 15 19 days and at $100 \%$ hasten following by about $12-15$ days in the first and second seasons respectively. Shading with wastewater at $100 \%$ has no significant effect in this respect

\section{INTRODUCTION}

Tomato (Lycopersicon esculantum, L. Mill; Solanaceae) is one of the most important vegetable and industrial crop in Egypt. The commercial plantation of tomato are gradually concentrated in the vicinity of cities nearest the industrial factories in the presence of polluted wastewater. Water availability is thought to be the most critical limiting factor for photosynthesis and hence for agriculture productivity.

Response of plants to wastewater stress is influenced by the degree of stress, plant genotypes and its growth stage as well as the environmental conditions.

On the other hand, competition for cultivated area and available fresh irrigation water especially in favor of summer crops, in Egypt has shifted interest towards increases efficiencies of the limited land use and growth resources utilization through intercropping. Tomato has tap root system whereas maize has a fibrous one. Consequently, there is a complementarily 
Helali, M.N. et al.

in the economic use of soil, water and nutrients by the two crops during their intercropping. In addition, maize height may produce shading demands for tomato and minimize its flowers abscission noticed through summer season.

The present investigation was detected to study the ability of using the waste water of El-Delta company of fertilizers and Talkha electricity generation mixed with the sewage of the vicinity villages at Dakahlia, ElDakahlia Governorate, Egypt as a common source of irrigation and nutrients for cultivation of two newly tomato genotypes grown in an intercropping pattern with maize. A comparative morphlogical characters were studied.

\section{MATERIALS AND METHODS}

Two field experiments were carried out at the Agric Exp. Station, Faculty Agric., Mansoura Univ., Egypt during the two growing summer season of 2007/2008 and 2008/2009 aiming to evaluate morphologically two tomato genotypes grown under wastewater of El-Delta company of fertilizers and Talkha electricity generation mixed with sewage of the vicinity villages, at Dakahlia Governorate, Egypt. Tomato seeds were performance were grown either alone or in association with maize. The fresh water was obtained from river Nile and used as a control. Tomato (Lycopercicon esculantum, Mill, Solanacea) genotypes 448 and G512 Sigma Comp. (imported from Holland) were evaluated in the present investigation. Zea mays, L Poaceae Cv. Bachaier 13 was used in an intercropping pattern as a shading agent for tomato growth. Corn grains were obtained from Agric. Res. Center (ARC), ministry of Agric. Egypt. Table (1) shows the identification characteristics of the tomato and corn genotypes and their sources used in the present investigation.

Table (1): Identification characteristics and sources of the tomato and corn genotypes used in the present investigation during the two growing summer seasons of 2007 and 2008.

\begin{tabular}{|c|c|c|}
\hline Genotype & Identifications characters & Source \\
\hline \begin{tabular}{l|l} 
Tomato, & 7 \\
Cultivar & (1): \\
Cheyenne & F \\
(E 448) FI & 9 \\
hybrid: & i \\
&
\end{tabular} & $\begin{array}{l}\text { Type : Cheyenne is an early determinate hybrid tomato of the bush type, for } \\
\text { production in the open field. } \\
\text { Plant: The plants are medium vigorous with medium internodes. } \\
\text { Fruit: Firm, deep globe fruit with a medium greenback. Average fruit weight of } 150 \\
\text { grams. Attractive red colour at maturity. } \\
\text { Resistance: Verticillium dahliae }+ \text { V. alboartum (VaVd) fusarium oxysporum f.sp. } \\
\left.\text { lycopersici (fol }{ }_{1-2} \text { ) races } 1 \text { and } 2 \text {, tomato Mosaic Virus (ToMV }{ }_{0-2}\right) \text {. } \\
\text { Tolerance: Tomato Yelow Leaf Curl Virus (TYLCV). } \\
\text { Remarks: Thanks to its earliness and TYLCV tolerance it can be sown very early } \\
\text { in the fall. The plant is bushy and covers the fruit well. }\end{array}$ & Holland \\
\hline \begin{tabular}{l|l} 
Tomato, \\
Cultivar (2) \\
: GS 12 F1F \\
hybrid:
\end{tabular} & $\begin{array}{l}\text { Type: Very early determinate hybrid for the fresh market, but also for paste and } \\
\text { juice industry, suitable for open field culture, either flat or low tunnels. } \\
\text { Plant: Medium - large vigorous plant, providing good fruit cover. } \\
\text { Fruit: Produces firm, globe, } 4 \text { to } 5 \text { locular fruit with green shoulder. Flavour is } \\
\text { excellent, with average weight of } 140 \text { grams, has a very good red color with } \\
\text { tolerance to cracking \& Blotchy ripening. } \\
\text { Resistance: Fusarium oxysporum f.sp. lycopersici (fo/1) race } 1 \text {, Verticillium dahliae } \\
+ \text { V. alboartum (VaVd). } \\
\text { Remarks: Recommended to increase the dose of nitrogen fertilizer before fruit } \\
\text { setting and as soon as plant makes a balance between generative and vegetative } \\
\text { growth. Adaptable variety that can grow under different environmental conditions \& } \\
\text { seasons. }\end{array}$ & Holland \\
\hline \begin{tabular}{|l} 
Corn, \\
Bachaier \\
13 \\
\end{tabular} & $\begin{array}{l}\text { Single cross, large plant height, medium maturity }(62-64 \text { days to mid tasseling and } \\
115-120 \text { days to harvesting, leaves still green up to harvesting, high yielding, } \\
\text { number of rows ear } 18 \text {, ear length } 25-28 \mathrm{~cm} \text { shelling } \% 84-86 \%) \text {. }\end{array}$ & $\begin{array}{l}\text { Egyptian } \\
\text { Agric. } \\
\text { Company }\end{array}$ \\
\hline
\end{tabular}


Soil samples and analyses:

Before the experimental design, twenty surface samples $(10-20 \mathrm{~cm}$ depth) were taken at 10 different location, air dried, mixed thoroughly and kept in plastic bags for analysis.

The mechanical and the chemical analysis of the soil used were carried out in the two growing seasons as described by Jackson (1973) and Page et al., (1982) and presented in Table (2).

Table (2): The physiochemical properties of the experimental soil used during the two growing seasons of 2007 and 2008.

\begin{tabular}{|c|c|c|c|c|c|c|c|c|c|c|}
\hline \multirow{3}{*}{ Season } & \multirow{2}{*}{\multicolumn{4}{|c|}{$\begin{array}{l}\text { 1. Mechanical Analysis } \\
\text { Soil Fraction } \%\end{array}$}} & \multirow{2}{*}{\multicolumn{2}{|c|}{ Organic }} & \multirow{3}{*}{$\begin{array}{c}\text { Calcium } \\
\text { carbonate }\end{array}$} & \multirow{3}{*}{\multicolumn{2}{|c|}{$\begin{array}{c}\text { pH (1:25 } \\
\text { Soil:Water } \\
\text { suspension) }\end{array}$}} & \multirow{3}{*}{$\begin{array}{l}\text { Soil } \\
\text { texture }\end{array}$} \\
\hline & & & & & & & & & & \\
\hline & $\begin{array}{l}\text { Coarse } \\
\text { sand }\end{array}$ & $\begin{array}{l}\text { Fine } \\
\text { sand }\end{array}$ & Silt & Clay & \multicolumn{2}{|c|}{ Matter } & & & & \\
\hline 2007 & 2.40 & 21.46 & 27.11 & 49.09 & 0.9 & & 2.18 & \multicolumn{2}{|c|}{7.80} & \multirow{2}{*}{ Clayey } \\
\hline \multirow[t]{4}{*}{2008} & 2.38 & 22.00 & 25.00 & 50.62 & 0.9 & & 2.16 & & 85 & \\
\hline & \multicolumn{10}{|c|}{ 2. Chemical Analysis } \\
\hline & \multirow{2}{*}{\multicolumn{2}{|c|}{$\begin{array}{c}\mathrm{EC} \mathrm{dsm}^{-1} \text { soil paste } \\
\text { extract at } 25 \mathrm{C}^{\circ}\end{array}$}} & \multicolumn{4}{|c|}{ CATIONS (meq/L) } & \multicolumn{4}{|c|}{ ANIONS (meq/L) } \\
\hline & & & $\mathrm{Ca}^{++}$ & $\mathbf{M g}^{++}$ & $\mathrm{Na}^{+}$ & $\mathrm{K}^{+}$ & $\mathrm{HCO}_{3}^{-}$ & $\mathrm{CO}_{3}^{--}$ & $\mathrm{SO}_{4}^{--}$ & $\mathrm{CL}^{-}$ \\
\hline 2007 & 1. & & 5.11 & 4.06 & 11.00 & 0.37 & 1.99 & - & 7.86 & 10.69 \\
\hline \multirow[t]{4}{*}{2008} & 1. & & 5.03 & 4.00 & 11.16 & 0.33 & 1.75 & - & 7.57 & 11.20 \\
\hline & \multicolumn{10}{|c|}{ 3. Nutrients Analysis } \\
\hline & \multicolumn{10}{|c|}{$\mathrm{mg} / 100 \mathrm{~g}$ soil } \\
\hline & \multirow{2}{*}{\multicolumn{3}{|c|}{$\frac{N}{27}$}} & \multirow{2}{*}{\multicolumn{4}{|c|}{$\mathrm{P}$}} & \multicolumn{3}{|c|}{$\mathrm{K}$} \\
\hline 2007 & \multirow{2}{*}{\multicolumn{3}{|c|}{$\frac{27}{30}$}} & \multirow{2}{*}{\multicolumn{4}{|c|}{8.5}} & \multicolumn{3}{|c|}{352.72} \\
\hline 2008 & & & & & & & & \multicolumn{3}{|c|}{346.33} \\
\hline
\end{tabular}

\section{Experimental design:}

Farm yard manure has been added during soil preparation at dose $40 \mathrm{~m}^{3} / \mathrm{fed}$. The experimental comprised 12 treatments which represents combination of two tomato genotypes, three wastewater irrigation levels and 2 intercropping pattern. A split -split plot design with three replication was used in both seasons. The tomato genotypes were arranged in the main plots where irrigation levels and cropping pattern were assigned at random in the sub and sub sub plots respectively.

Each experimental unit area was $9 \mathrm{~m}^{2}$ contained two rows $4.5 \mathrm{~m}$ in length and one meter width, water irrigation tested were: fresh water from the river Nile (control), $50 \%$ wastewater $+50 \%$ fresh water and $100 \%$ waste water which denoted $I_{1}, I_{2}$ and $I_{3}$ respectively. The chemical analysis of the fresh water and wastewater according to (Jackson, 1973) are presented in Table (3).

\section{The cropping patterns recorded different shade densities were:}

1- Pure stands of tomato (control); $0 \%$ shading density; tomato plants grown under full day light intesity; S1.

2- One side of the ridge tomato altered with maize on the other side; $50 \%$ shading density of the full day light; S2.

Light intensity was measured by lux-meter just over the tomato plants during their growth and calculated as $\%$ of the full day light. 
Helali, M.N. et al.

Table (3): Physio-chemical characteristics of the irrigation water used (fresh water, $50 \%$ wastewater and $100 \%$ waste water) in $\mathrm{mg} / \mathrm{l}$ as specified.

\begin{tabular}{|c|c|c|c|}
\hline $\begin{array}{c}\text { Physio-chemical } \\
\text { character }\end{array}$ & $\begin{array}{l}\text { Fresh } \\
\text { water } \mathrm{I}_{1}\end{array}$ & $\begin{array}{c}50 \% \text { waste } \\
\text { water } \mathrm{I}_{2}\end{array}$ & $\begin{array}{c}100 \% \text { waste } \\
\text { water } I_{3}\end{array}$ \\
\hline $\mathrm{Ec} \mathrm{dsm}^{-1}$ & 0.31 & 5.50 & 11.56 \\
\hline $\mathrm{pH}$ & 7.9 & 8.1 & 8.2 \\
\hline Total dissolved Solids (TDS) & 2.00 & 409 & 1000 \\
\hline Total solids (TS) & 605 & 1150 & 2489 \\
\hline Total suspended solids (TSS) & 250 & 400 & 950 \\
\hline \begin{tabular}{|l|l|} 
& $\mathrm{Ca}^{++}$ \\
Cations & $\mathrm{Mg}^{++}$ \\
$\mathrm{K}^{+}$ \\
& $\mathrm{Na}^{+}$ \\
& $\mathrm{NH}_{3}-\mathrm{N}^{+}$
\end{tabular} & $\begin{array}{c}20.20 \\
10.00 \\
5.20 \\
10.61 \\
0.09\end{array}$ & $\begin{array}{c}30.71 \\
40.51 \\
11.10 \\
20.41 \\
3.11\end{array}$ & $\begin{array}{c}60.33 \\
90.62 \\
20.20 \\
40.91 \\
6.90\end{array}$ \\
\hline $\begin{array}{l}\mathrm{HCO}_{3}^{-} \\
\mathrm{CO}_{3}^{--} \\
\mathrm{Cl}^{-} \\
\mathrm{PO}_{4}^{--} \\
\mathrm{NO}_{3}-^{-} \mathrm{N}^{-} \\
\mathrm{SO}_{4}^{--}\end{array}$ & $\begin{array}{c}8.60 \\
0.00 \\
25.00 \\
0.42 \\
0.11 \\
11.97\end{array}$ & $\begin{array}{c}20.71 \\
16.22 \\
50.00 \\
1.52 \\
3.60 \\
15.79\end{array}$ & $\begin{array}{c}38.27 \\
40.00 \\
100.67 \\
1.99 \\
7.22 \\
30.81\end{array}$ \\
\hline
\end{tabular}

In both seasons, seeds of the two tested tomato genotypes were sown on $15^{\text {th }}$ March in foam pots, under the greenhouse condition and the seedling, 30 days in age, were transplanted at $30 \mathrm{~cm}$ apart. At the same time of tomato sowing, maize grains were hand planted at the rate of 4 grains per hill, $0.30 \mathrm{~cm}$ apart. Thinning of corn seedling was took place after two weeks from sowing to leave one seedling / hill on the other side of the same ridges. Fertilization, and other agricultural practices for tomato cultivation were uniformly applied according to the recommendations of vegetables research institute center ARC. Egypt.

\section{Morphological observation:}

A random sample of the two tomato plant genotypes were taken from every experimental unit at 35 and 70 days from transplanting to measuring the following data. 1-Main stem height; $\mathrm{cm}, 2$ - Number of internodes on the main stem, 3-Fresh and Dry weight at $70{ }^{\circ} \mathrm{C}$ of the shoot per plant $(\mathrm{gm}), 4-$ Number of branches on the main stem, 5- Leaf number, 6- Number of clusters /plant 7- Leaf area /plant, were recorded.

Leafy area was measured by disk method (Johanson 1967). Using the following formula:

Leaf area $/$ plant $\left(\mathrm{cm}^{2} /\right.$ plant $)=$ Leaf dry weight $(\mathrm{g}) \times$ disk area $\left(\mathrm{cm}^{2}\right)$

$$
\text { Disk dry weight }(\mathrm{g})
$$

For dry weight determination, four tomato plants from each treatment were dried, after taking their fresh weight, in hot air oven at $70{ }^{\circ} \mathrm{C}$ for two days and weighted up to a constant.

\section{Statistical analysis:}

The analysis of variance was done in the present investigation as regular two way classification out-lined by Gomez and Gomez (1984). 


\section{RESULTS AND DISSCUSION}

\section{Vegetative growth parameters:}

Comparing the two leasted tomato genotypes, data tabulated in Tables (4-10) show a significant differences among them regarding their growth parameters studied at different growth stages in both seasons. Cheyenne (e 448) F1 hybrid was the most vigorous growth comparing to Gs $12 \mathrm{~F} 1$ hybrid. Therefore, genotypes (1) recorded an increase in all growth parameters studied and reached to the level of significant at $0.05 \%$. The increase in plant height of genotypes (1) more than the other (2) are mainly due to the increase in both number and length of the internods. The superiority of genotypes (1) growth might be attributed to the heredity factor and genetical composition of the genotype used.

Regarding the effect of wastewater levels, data presented in the same tables indicate that, all growth parameters studied of the two tested tomato genotypes represented by plant height, numbers of internodes, leaves and branches on the main stem, as well as, fresh and dry weight of the shoot system were increased at $50 \%$ level whereas decreased at $100 \%$ level of the wastewater used. These results are true throughout the experimental period during the two growing seasons. However, such decreases were insignificant difference at $0.05 \%$ level in the two growing seasons. The noticed increase at $50 \%$ wastewater level may be due to the presence of excess $\mathrm{NH}_{4}-\mathrm{N}$ in the waste water used (Table 3). In the this context, (Tantawy (2000) concluded that $\mathrm{N}$ is an indispensable elementary constituent of numerous organic compounds of general importance; amino acids, protein, and nucleic acids and its needed for formation of protoplasm and new cells as well as its encouragement for cell elongation. The decreases recorded at the 100\% level of wastewater may be ascribed to the high osmotic pressure of it and the soil solution in addition to the presence of salinity (Table 3 ), which restricted the absorption of water by tomato roots and /or to the toxic effects of certain ions especially that of $\mathrm{NH}_{4}-\mathrm{N}$ and their effects on photosynthetic rates, translocation and migration of metabolic substances to the different plant organs. Beside, water stress has been shown to reduce the photosynthesis, net assimilation rate, of DNA, RNA and protein whereas, increased photorespiration rate in many plant species. All these factor might lead to disturbance in metabolic activities, cell division and elongations and the activities of the mitochondria and chloroplasts were reduced. These explanation, were supported by Helaly (1984), Helaly et al., (1985 a\&b), Ghallab and Nesiem (1999) and Ghallab and El-Ghadban (2003 \&2004). Hayward and Long (1943) noticed that water stress caused by high osmotic potential decreased activities of meristematic and cambial cells and led to maturation of small cell size. El-Dodo (1976) found that water stress was a direct effect on the reduction in dry weight content of all sesame organs which was accumulative of reduce plant size, reduced number of roots and leaves as well as total leaf area. He added that, reduction of growth under water stress reflects metabolic insufficiency resulting from relative unavailability of water and minerals. El-Shafey et al., (2003) stated that when plants are subjected to water stress certain physiological response including 
Helali, M.N. et al.

wilting and stomatal closure usually enhanced rates of leaf senescence and therefore, decreased assimilation rate and plant growth. They added that, all these processes might be attributed to hormonal changes in addition to other factors such as minerals deficiencies and dehydration. The relation between the onset of water stress and the elevation of ABA level in maize leaf tissues has been previously demonstrated (Beardsell and Cohen, 1975). It seems that, ABA present in stressed leaves may move from the mesophyl to the grad cells in response to stress and this induce stomatal closure. Moreover, it was reported that $\mathrm{N}$ toxicities are characterized by poor growth rate, the leaves remain small of the stem have a spicndly appearance (Hutung, 2004).

The effect of alkaline water stress on phosphorus deficiency was previously reported (Helaly et al., 1985-b). Tantawy, (2000) on tomato stated that, phosphorus is a part of the molecular structure of several vitally important compounds, notably nucleic acids (DNA; the two forms of m RNA and t RNA). He added that, phosphorus plays an indispensable role in the enzyme system necessary for the energy transform in photosynthetic and respiration, it is also a constituent of cell nucleus and essential for division and for the development of the meristematic tissues.

As for the effect of intercropping, pattern as a shading agent on tomatoes growth, it is quite clear from the data presented in the same Tables (4-10) that shading seemes to have a stimulating effect on different growth characters of, both tomato genotypes under the present investigation compared with the control; pure tomato cultivation stand under full light intensity. Stem height, numbers of internodes, leaves and branches and leaf area/ plant as well as, fresh and dry weight of the shoot were increased under shadding by maize cultivation intercropped with tomato. These results are true throughout the experimental period during both growing seasons. The promoting effects of shading on tomato growth might be due to a retardation in the conversion of cells to their differentiation phase and /or its effects on increasing GA level (Salisbury and Ross, 1992).

These results are true in both tomato genotypes examined and grown in the two growing seasons throughout the experimental period. In other words, increasing light intensity to $100 \%$ of full day light as a results of pure tomato cultivation caused a reduction in shoot height and all other growth parameters studied under the investigation. Moreover, it is clear from the same tables that the 2 nd sample was more affected than the 1 st in both genotypes. In addition, the values recorded with genotype (1) were significantly higher than those of genotype (2). Therefore, it may be assumed that the increase in plant height and growth vigour resulting from shading by intercropping with maize is hindered if shade density exceeds to $100 \%$ of full day light. The increasing effects of shading on tomato growth represented by the dry matter accumulation indicated to an increase in different plant parts.

These increases could be considered as a reliable index to the photosynthetic efficiency of the plant. The early decrease in dry matter accumulation in genotype (2) plants compared with genotype (1) especially under shading may be due to a relatively low rate of photosynthesis and most of anabolic processes while respiration and translocation of various materials to reproductive organs may proceed at normal rates. On the other hand, the 
decrease in dry matter accumulation in the control plants; pure cultivation without shading is actually due to senescence which is usually accompanied with loss and withering of plant organs as well as to the active transport of elaborated materials to the fruit under full light intensity. In this context, it was found that, light intensity may enhance the photosynthetic, activities and sugar content. At the same time, it decreased water content within the plant tissues (Hutung, 2004). Therefore, plant development was shifted more rabidly towards maturity and senescence under full day light and this might be responsible for the inferiority of its shoot length. It could be mentioned that shading enabled the developing tomato plants to withstand, to some extent the unfavorable effect of high temperature and light intensity recorded in summer seasons.

(Salisbury and Ross, 1992) reported that the dry matter accumulation was essentially proportional to the light intensity in several plant species.

Results in the present investigation show also that, plant height, number of stem, leaves, internodes and branches, as well as fresh and dry weights were increased consistently with advancing in age. The "S" or sigmoid growth curve was observed in both tomato genotypes studied; since the highest rate of such increase was detected between the $1^{\text {st }}$ and the $2^{\text {nd }}$ sampling date indicating a rapid growth during this period. The continous increase in growth with advancing age may be assumed to the progressing building up of a new tissues from leaves and branches as well as an accumulation of some metabolites during their growth period. Moreover, the rate of building up the new tissues exceeded that of both catabolism and translocation of various nutrients towards other organs. However, the decline in dry weight content observed at maturity might be attributed to the loss of dead leaves and branches as well as to the relatively low rate of metabolic processes during such growth period.

With ranged to the effect of interaction treatments between the several factors under the present investigation; genotypes, wastewater irrigation level and cropping pattern, on tomato, the data, in general, did not reflect any significant effects on the different plant growth characters studied in the two growing seasons. However, growth of genotype (2) seem to have been more affected with wastewater level interacted with cropping pattern than genotype (1) which tolerant wastewater stress especially under shading condition. The general effect of high level of wastewater stress at $100 \%$ was dwarfing and stunting in genotype (2) of tomato. It seems that plants of genotype (2) were growing slowly and were inferior in size, and unhealthy in general appearance compared with genotype (1) at the same corresponding level. Moreover, genotype (2) stem were thin and the rate of the leaf production and leaf size were much reduced. Plants showed obvious changes in colour if compared to the control or genotype (1). The leaves became dull coloured, often bluish, green and frequently coated with a waxy deposit and epidermal hairs especially in plants growth under full light intensity. The data also show that shading of both tomato genotypes with the superiority of genotype (1) resulted in plants having greater branches and leaves when irrigated with fresh water (control) as well as that irrigated with wastewater at $50 \%$. The lowest values were recorded in shaded plants 
Helali, M.N. et al.

irrigated with $100 \%$ wastewater throughout most estimated dates in the two growing seasons. However, the differences between control values and that obtained at $100 \%$ wastewater was insignificant in both tomato genotypes.

It could be concluded that shading tomato by cultivated it under an intercropping pattern of maize, counteracted the harmfull effects of wastewater stress at high level on decreasing various growth parameters depending on the genotypes examined compared with the corresponding control. The best vigorous vegetative growth in both tomato genotypes studied, was recorded in plants grown under shading and irrigated with 50\% wastewater with the superiority of genotype (1). Eisa, (1998) reported that water stress substantially induces loss of turger which affects on the rate of cell expansion and ultimate cell size, consequently decreased growth rat, stem elongation, leaf expansion and stomatal operture.

The superiority of genotype (1) than genotype (2) may be due to, as indicated by the result obtained in the present investigation, an accumulation of IAA associated with high levels of cytokinens as well as sugars in the shoot of cultivar (1) plant compared with those of genotype (2) as showed by Helaly et al., (2009). These results induced cultivar (1) to keep better performance against water stress and toxicities and gives some sort of resistance against wilting. Such mechanism is well know as osmotic adjustment which can be accomplished by creating more negative osmotic potentials through the accumulation of the organic osmolytes (sugars and others) within the root cell as an adaptable mechanism against either biotic or biotic stress (Hatung, 2004). Sugar as osmolytes enable plants to keep better water relation under stress conditions by increasing the ability of their roots to extract more water from even the saline soil (Hanafy Ahmed et al., 2002).

The beneficial effects of shading against wilting showed an increase in tomato growth which may be due its effects on increasing cells number and size as well as water absorption (Helaly et al., 1985 a\&b). Bakry (1973) on pea plant reported that shading increased the amount of metabolic synthesized per unit period, nutrient absorption and total carbohydrates. The influence od $\mathrm{Zn}$ as an activator of several oxidative enzymes (Hatung, 2004) biosynthesis of Auxins (Jeffrey, 1987) increasing photosynthesis capacity and net assimilation metabolites were recorded. Similarly, the beneficial effect of the wastewater is not far to seek. It contained, in addition to the three major element NPK, some other essential elements like $\mathrm{S}, \mathrm{Ca}, \mathrm{Mg}$ and $\mathrm{Cl}$ which might have contributed towards the improvement of growth specially the shoot fresh weight and leaf number which are so important for good yield. The roles of NPK and other nutrients were previously reported (Salisbury and Ross, 1992).

2-Flowering:

Data in Table (11) indicate that number of days from transplanting to the beginning of flowering were considerably affected by the genotypes that investigated. Generally genotype (2) bloomed earlier than genotype (1); more resistance by about 7-10 days in the first and second seasons respectively overall the wastewater levels and the intercropping pattern treatments. Therefore, genotype (2) showed shorter growing period and earlier maturation than genotype (1). This may be due to the differences in their 
ability to tolerant the environmental conditions under stresses. It may be emphasized that the kind as well as the amount of the fertilizer to be applied depends, to large extent, on the type of the genotype grown and mode of its application. Wastewater used as common resource of nutrients and water indicated that the judicions supply of nutrients can play an indispensable role in the realization of the full genetic potential of the growing genotypes.

Wastewater at $50 \%$ level intercropping pattern, overall, as a shading agent, increased the period elapsed from transplanting to flowering since; control plants in both genotypes started to bloom earlier than did in other treatments. This may be due to a stimulation effect of the relatively slight wastewater (riched in $\mathrm{NH}_{4}-\mathrm{N}$ ) level in irrigation water and its effects on growth vigour. Similarly, wastewater at $100 \%$ level had a delaying effect on flowering date. (1) which amounting to 15-19 days in the first and second seasons respectively. The delaying in flowering may be due to the high growth vigour noticed in genotype 1 and indicating that this genotype has an ability to tolerance high levels of wastewater examined. The reverse of this trend was true in genotype (2) which started to bloom earlier under wastewater at $100 \%$ level than did in the others. The difference was about 12-15 days in both seasons respectively. This might be caused by retardation of vegetative growth which consequently reflected in a decrease of flower production. Helaly et al., (2009) mentioned that the checking of vegetative growth due to stress may hasten maturation and final harvesting dates especially with crops having indeterminate growth habits such as potatoes, tomatoes, melon ........etc. Moreover, data in the present investigation indicate that wastewater, in general, proved a good source of nutrients especially under shading condition. Its application improved the performance of both vegetative and reproductive organs. This improvement may be ascribed to the regular supply of some essential nutrients from the irrigating wastewater.

The data indicate also that shading significantly enlowered the number of days from transplanting tomato up to flowering. This was true during the two growing seasons. As it has been mentioned before, shading decreased number of leaves and branches, consequently, it can be stated that tomato plants under full light intensity were more efficient in building the reproductive organs as compared with shading. Unlike these results, Bakry (1973) found that pea plants grown under high light intensity produce their flowers somewhat earlier as compared with shaded ones. Similarly Goma (1966) on tomato recorded that shading retarded flowering. The hasten effects of shading on tomato flowering noticed in the present investigation especially under $100 \%$ wastewater may be due to the role of it on encouraging the meristimatic activities to create a strong and healthy tomato plants which intern push the plants towards building its several organs early. 
Helali, M.N. et al.

Table (4): Plant height of the two tomato genotypes (C) as affected by irrigation with waste water levels, (I) shading by an intercropping pattern (S) and their interactions throughout the experimental period of the two growing seasons 20072008 and 2008-2009.

\begin{tabular}{|c|c|c|c|c|c|c|c|}
\hline \multicolumn{4}{|c|}{ Characters } & \multicolumn{4}{|c|}{ Plant height (cm) } \\
\hline \multirow{2}{*}{\multicolumn{4}{|c|}{ Growth stage }} & \multicolumn{2}{|c|}{ ro days } & \multicolumn{2}{|c|}{$v \cdot$ days } \\
\hline & & & & 2007 & 2008 & 2007 & 2008 \\
\hline \multirow{9}{*}{ CV1 } & \multirow{3}{*}{$\begin{array}{l}\text { Fresh water } \\
\text { (Control) }\end{array}$} & \multicolumn{2}{|c|}{ Tomato pure } & 51.5 & 54.6 & 85.8 & 16.8 \\
\hline & & \multicolumn{2}{|c|}{ Tomato + corn } & 66.8 & 70.3 & 110.8 & 23.5 \\
\hline & & \multicolumn{2}{|c|}{ Mean } & 59.15 & 62.75 & 98.30 & 20.15 \\
\hline & \multirow{3}{*}{$50 \%$} & \multicolumn{2}{|c|}{ Tomato pure } & 68.5 & 70.0 & 95.7 & 28.5 \\
\hline & & \multicolumn{2}{|c|}{ Tomato + corn } & 78 & 80.3 & 110.9 & 30.2 \\
\hline & & \multicolumn{2}{|c|}{ Mean } & 73.25 & 75.15 & 103.3 & 29.35 \\
\hline & \multirow{3}{*}{$100 \%$} & \multicolumn{2}{|c|}{ Tomato pure } & 51.5 & 56.3 & 79.8 & 15.9 \\
\hline & & \multicolumn{2}{|c|}{ Tomato + corn } & 73.2 & 75.6 & 110.8 & 25.9 \\
\hline & & \multicolumn{2}{|c|}{ Mean } & 62.35 & 65.95 & 95.3 & 20.9 \\
\hline \multirow{9}{*}{ CV2 } & \multirow{3}{*}{$\begin{array}{l}\text { Fresh water } \\
\text { (Control) }\end{array}$} & \multicolumn{2}{|c|}{ Tomato pure } & 39.7 & 41.1 & 95.7 & 10.1 \\
\hline & & \multicolumn{2}{|c|}{ Tomato + corn } & 60.4 & 65.6 & 110.9 & 14.8 \\
\hline & & \multicolumn{2}{|c|}{ Mean } & 50.05 & 53.35 & 103.3 & 12.45 \\
\hline & \multirow{3}{*}{$50 \%$} & \multicolumn{2}{|c|}{ Tomato pure } & 62.5 & 67.8 & 90.2 & 16.6 \\
\hline & & \multicolumn{2}{|c|}{ Tomato + corn } & 73.7 & 78.2 & 104.7 & 20.4 \\
\hline & & \multicolumn{2}{|c|}{ Mean } & 68.1 & 73.0 & 97.45 & 18.5 \\
\hline & \multirow{3}{*}{$100 \%$} & Tomato $\mathrm{p}$ & & 49.5 & 52.9 & 56.2 & 9.5 \\
\hline & & Tomato + & orn & 68.8 & 71.8 & 104.9 & 16.2 \\
\hline & & Mean & & 59.15 & 62.35 & 80.55 & 12.85 \\
\hline & & & Cv1 & 57.16 & 60.3 & 87.1 & 20.4 \\
\hline & Magn & Tomato pure & Cv2 & 50.56 & 53.93 & 80.7 & 12.06 \\
\hline & Mean & Tomato + & Cv1 & 72.66 & 51.4 & 110.8 & 26.53 \\
\hline & & corn & Cv2 & 67.63 & 71.86 & 106.8 & 17.13 \\
\hline & & A-Cultive & & 0.083 & 0.0726 & 3.269 & 0.0726 \\
\hline & D $0.05 \%$ & B-Wastew & ter & 0.076 & 0.108 & 4.237 & 0.108 \\
\hline & & C-Intercrop & ping & 0.165 & 0.083 & 6.454 & 0.083 \\
\hline & & $A \times B$ & & $\star * * *$ & $\star * * *$ & * & $\star * * *$ \\
\hline & tian & $A \times C$ & & $\star \star * *$ & $\star \star \star *$ & N.S & $* * *$ \\
\hline & teraction & $A X B X$ & & 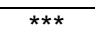 & $* * *$ & N.S & $* * *$ \\
\hline & & B X C & & $\star \star \star *$ & $* * *$ & $* \star *$ & $* * *$ \\
\hline
\end{tabular}


Table (5): Number of internodes of the two tomato genotypes (C) as affected by irrigation with waste water levels, (I) shading by an intercropping pattern (S) and their interactions throughout the experimental period of the two growing seasons 2007-2008 and 2008-2009.

\begin{tabular}{|c|c|c|c|c|c|c|c|}
\hline \multicolumn{4}{|c|}{ Characters } & \multicolumn{4}{|c|}{ Number of internodes } \\
\hline \multirow{2}{*}{\multicolumn{2}{|c|}{ Treatments }} & \multirow{2}{*}{\multicolumn{2}{|c|}{ Growth stage }} & \multicolumn{2}{|c|}{ 35days } & \multicolumn{2}{|c|}{$v \cdot$ days } \\
\hline & & & & 2007 & 2008 & 2007 & 2008 \\
\hline \multirow{9}{*}{ CV1 } & \multirow{3}{*}{$\begin{array}{c}\text { Fresh } \\
\text { water } \\
\text { (Control) }\end{array}$} & \multicolumn{2}{|c|}{ Tomato pure } & 10.7 & 11.9 & 14.6 & 16.8 \\
\hline & & \multicolumn{2}{|c|}{ Tomato + corn } & 20.0 & 21.8 & 25.7 & 23.5 \\
\hline & & \multicolumn{2}{|c|}{ Mean } & 15.35 & 16.86 & 20.15 & 20.15 \\
\hline & \multirow{3}{*}{$50 \%$} & \multicolumn{2}{|c|}{ Tomato pure } & 20.5 & 23.2 & 26.6 & 28.5 \\
\hline & & \multicolumn{2}{|c|}{ Tomato + corn } & 28.5 & 30.0 & 29.5 & 30.2 \\
\hline & & \multicolumn{2}{|c|}{ Mean } & 24.5 & 26.6 & 28.05 & 29.35 \\
\hline & \multirow{3}{*}{$100 \%$} & \multicolumn{2}{|c|}{ Tomato pure } & 10.4 & 11.2 & 14.3 & 15.9 \\
\hline & & \multicolumn{2}{|c|}{ Tomato + corn } & 22.5 & 24.5 & 23.3 & 25.9 \\
\hline & & \multicolumn{2}{|c|}{ Mean } & 16.45 & 17.85 & 18.8 & 20.9 \\
\hline \multirow{9}{*}{ CV2 } & \multirow{3}{*}{$\begin{array}{c}\text { Fresh } \\
\text { water } \\
\text { (Control) }\end{array}$} & \multirow{2}{*}{\multicolumn{2}{|c|}{$\begin{array}{l}\text { Tomato pure } \\
\text { Tomato + corn }\end{array}$}} & 7.2 & 8.2 & 9.8 & 10.1 \\
\hline & & & & 13.9 & 15.5 & 11.8 & 14.8 \\
\hline & & \multicolumn{2}{|c|}{ Mean } & 10.55 & 11.85 & 10.8 & 12.45 \\
\hline & \multirow{3}{*}{$50 \%$} & \multicolumn{2}{|c|}{ Tomato pure } & 15.3 & 18.8 & 13.9 & 16.6 \\
\hline & & \multicolumn{2}{|c|}{ Tomato + corn } & 22.5 & 20.11 & 16.7 & 20.4 \\
\hline & & \multicolumn{2}{|c|}{ Mean } & 18.9 & 19.45 & 15.3 & 18.5 \\
\hline & \multirow{3}{*}{$100 \%$} & \multicolumn{2}{|c|}{ Tomato pure } & 6.5 & 7.4 & 9.2 & 9.5 \\
\hline & & Tomato + & orn & 15.8 & 17.2 & 10.5 & 16.2 \\
\hline & & Meal & & 11.15 & 12.3 & 9.85 & 12.85 \\
\hline & & Tomato & Cv1 & 13.87 & 15.43 & 18.5 & 20.4 \\
\hline & Man & pure & Cv2 & 9.67 & 14.47 & 10.97 & 12.07 \\
\hline & Iviean & Tomato + & Cv1 & 23.67 & 25.43 & 26.17 & 26.53 \\
\hline & & corn & Cv2 & 17.4 & 17.6 & 13 & 17.13 \\
\hline & & A-Cultis & & 0.102 & 0.083 & 0.083 & 0.072 \\
\hline & D 0.05\% & B-Wastel & ater & 7.929 & 0.768 & 0.0543 & 0.108 \\
\hline & & C-Intercro & ping & 1.0190 & 0.165 & 0.165 & 0.082 \\
\hline & & $A X$ & & $* *$ & $* *$ & $* *$ & $* *$ \\
\hline & & $A \times$ & & ** & ** & $\star \star$ & ** \\
\hline & eraction & $\overline{A X B}$ & & ** & ** & ** & ** \\
\hline & & B X & & ** & ** & ** & ** \\
\hline
\end{tabular}


Helali, M.N. et al.

Table (6): Number of branches of the two tomato genotypes (C) as affected by irrigation with waste water levels, (I) shading by an intercropping pattern (S) and their interactions throughout the experimental period of the two growing seasons 2007-2008 and 2008-2009.

\begin{tabular}{|c|c|c|c|c|c|c|c|}
\hline \multicolumn{4}{|c|}{ Characters } & \multicolumn{4}{|c|}{ Number of branches } \\
\hline \multirow{2}{*}{\multicolumn{2}{|c|}{ Treatments }} & \multirow{2}{*}{\multicolumn{2}{|c|}{ Growth stage }} & \multicolumn{2}{|c|}{ ro days } & \multicolumn{2}{|c|}{$v \cdot$ days } \\
\hline & & & & 2007 & 2008 & 2007 & 2008 \\
\hline \multirow{9}{*}{ CV1 } & \multirow{3}{*}{$\begin{array}{c}\text { Fresh } \\
\text { water } \\
\text { (Control) }\end{array}$} & \multicolumn{2}{|c|}{ Tomato pure } & 6.5 & 7.6 & 11.7 & 12.63 \\
\hline & & \multicolumn{2}{|c|}{ Tomato + corn } & 11.3 & 15.33 & 18.33 & 19.7 \\
\hline & & \multicolumn{2}{|c|}{ Mean } & 17.8 & 11.465 & 15.015 & 16.165 \\
\hline & & \multicolumn{2}{|c|}{ Tomato pure } & 15.633 & 19.3 & 20.33 & 23.4 \\
\hline & $50 \%$ & \multicolumn{2}{|c|}{ Tomato + corn } & 24.766 & 28.5 & 30.1 & 32.33 \\
\hline & & \multicolumn{2}{|c|}{ Mean } & $r \cdot, 1990$ & $r r, q$ & $r 0, r_{0}$ & $r V, \Lambda \uparrow 0$ \\
\hline & \multirow{3}{*}{$100 \%$} & \multicolumn{2}{|c|}{ Tomato pure } & 7.43 & 9.63 & 13.366 & 14.47 \\
\hline & & \multicolumn{2}{|c|}{ Tomato + corn } & 13.7 & 18.73 & 20.266 & 23.6 \\
\hline & & \multicolumn{2}{|c|}{ Mean } & $1 ., 090$ & $1 \leqslant, 11$ & 17,117 & $19, .40$ \\
\hline \multirow{9}{*}{ CV2 } & \multirow{3}{*}{$\begin{array}{c}\text { Fresh } \\
\text { water } \\
\text { (Control) }\end{array}$} & \multicolumn{2}{|c|}{ Tomato pure } & 5.766 & 6.23 & 8.733 & 9.5 \\
\hline & & \multicolumn{2}{|c|}{ Tomato + corn } & 10.4 & 12.53 & 16.466 & 19.33 \\
\hline & & \multicolumn{2}{|c|}{ Mean } & $\Lambda, \cdot \Lambda r$ & $q, r \wedge$ & 14,0990 & $1 \leqslant, \leqslant 10$ \\
\hline & \multirow{3}{*}{$50 \%$} & \multicolumn{2}{|c|}{ Tomato pure } & 15.4 & 16.667 & 18.33 & 21.7 \\
\hline & & \multicolumn{2}{|c|}{ Tomato + corn } & 22.33 & 25.5 & 24.466 & 27.7 \\
\hline & & \multicolumn{2}{|c|}{ Mean } & 11,140 & $Y,, \wedge \varepsilon$ & $r), r q \wedge$ & $r \leqslant, V$ \\
\hline & \multirow{3}{*}{$100 \%$} & \multicolumn{2}{|c|}{ Tomato pure } & 6.6 & 8.4 & 10.333 & 11.66 \\
\hline & & Tomato & orn & 14.3 & 17.4 & 21.633 & 24.23 \\
\hline & & Mea & & $1 \cdot, \leqslant 0$ & $1 \cdot, \varepsilon$ & $10,9 \wedge r$ & $1 V, q \leq 0$ \\
\hline & & Tomato & Cv1 & 9.854 & 12.177 & 15.132 & 16.83 \\
\hline & Mean & pure & Cv2 & 9.255 & 10.43 & 12.464 & 14.29 \\
\hline & & Tomato + & Cv1 & 16.587 & 20.85 & 22.899 & 25.21 \\
\hline & & corn & Cv2 & 15.677 & 18.48 & 20.86 & 23.75 \\
\hline & & A-Culti & & 0.130 & 0.076 & 0.146 & 0.099 \\
\hline & D $0.05 \%$ & B-Waste & ter & 0.123 & 0.229 & 0.111 & 0.169 \\
\hline & & C-Intercrc & ping & 0.149 & 0.499 & 0.186 & 0.373 \\
\hline & & $A X$ & & $\star *$ & $\star \star *$ & ** & $\star *$ \\
\hline & orantion & $A X$ & & * & ** & N.S & ** \\
\hline & eraction & AX B & & $\star *$ & ** & N.S & ** \\
\hline & & B X & & $\star *$ & ** & $* \star$ & $\star *$ \\
\hline
\end{tabular}


Table (7): Fresh weight of the two tomato genotypes (C) as affected by irrigation with waste water levels, (I) shading by an intercropping pattern (S) and their interactions throughout the experimental period of the two growing seasons 20072008 and 2008-2009.

\begin{tabular}{|c|c|c|c|c|c|c|c|}
\hline \multicolumn{4}{|c|}{ Characters } & \multicolumn{4}{|c|}{$\begin{array}{l}\text { Fresh weight } \\
\end{array}$} \\
\hline \multirow{2}{*}{\multicolumn{2}{|c|}{ Treatments }} & \multirow{2}{*}{\multicolumn{2}{|c|}{ Growth stage }} & \multicolumn{2}{|c|}{ ro days } & \multicolumn{2}{|c|}{$v \cdot$ days } \\
\hline & & & & 2007 & 2008 & 2007 & 2008 \\
\hline \multirow{9}{*}{ CV1 } & \multirow{3}{*}{$\begin{array}{c}\text { Fresh } \\
\text { water } \\
\text { (Control) }\end{array}$} & \multicolumn{2}{|c|}{ Tomato pure } & 120.266 & 122.00 & 146.66 & 151.00 \\
\hline & & \multicolumn{2}{|c|}{$\begin{array}{c}\text { Tomato + } \\
\text { corn }\end{array}$} & 132 & 135.26 & 153.266 & 157.33 \\
\hline & & \multicolumn{2}{|c|}{ Mean } & 252.27 & 128.63 & 149.96 & 154.17 \\
\hline & & \multicolumn{2}{|c|}{ Tomato pure } & 125.8 & $1 \times 9, \leqslant 7$ & 162.366 & 159.53 \\
\hline & $50 \%$ & \multicolumn{2}{|c|}{$\begin{array}{l}\text { Tomato + } \\
\text { corn }\end{array}$} & 147.66 & 150.43 & 149.33 & 166.13 \\
\hline & & \multicolumn{2}{|c|}{ Mean } & YVY, $\leq Y$ & 149,90 & 100,10 & $17 r, \wedge r$ \\
\hline & \multirow{3}{*}{$100 \%$} & \multicolumn{2}{|c|}{ Tomato pure } & 123.466 & 125.40 & 156.266 & 155.66 \\
\hline & & \multicolumn{2}{|c|}{$\begin{array}{c}\text { Tomato + } \\
\text { corn }\end{array}$} & 133.4 & 136.86 & 118.73 & 161.366 \\
\hline & & Me & & $Y \circ \checkmark, \wedge V$ & $1 M 1,1 r$ & $\mid r v, \leq 91$ & 101,01 \\
\hline \multirow{9}{*}{ CV2 } & \multirow{3}{*}{$\begin{array}{c}\text { Fresh } \\
\text { water } \\
\text { (Control) }\end{array}$} & \multicolumn{2}{|c|}{ Tomato pure } & 95.5 & 97.00 & 125.66 & 121.33 \\
\hline & & \multicolumn{2}{|c|}{$\begin{array}{c}\text { Tomato + } \\
\text { corn }\end{array}$} & 106.66 & 108.46 & 125.33 & 130.30 \\
\hline & & \multicolumn{2}{|c|}{ Mean } & $Y, Y, 17$ & $I \cdot r, V r$ & $1 \times 0,0$. & Iro,Ar \\
\hline & \multirow{3}{*}{$50 \%$} & \multicolumn{2}{|c|}{ Tomato pure } & 105.33 & 110.76 & 138.73 & 127.33 \\
\hline & & \multicolumn{2}{|c|}{$\begin{array}{c}\text { Tomato }+ \\
\text { corn }\end{array}$} & 118.7 & 121.76 & 120.3 & 140.33 \\
\hline & & \multicolumn{2}{|c|}{ Mean } & 114,010 & $117, Y 7$ & $1 Y q, 0 r$ & $1 r r, \wedge r$ \\
\hline & \multirow{3}{*}{$100 \%$} & \multicolumn{2}{|c|}{ Tomato pure } & 99.66 & 99.33 & 129.766 & 123.66 \\
\hline & & \multicolumn{2}{|c|}{$\begin{array}{l}\text { Tomato + } \\
\text { corn }\end{array}$} & 109.0 & 112.33 & 110.934 & 136.53 \\
\hline & & $\mathrm{Me}$ & & $1 \cdot \varepsilon, r r$ & $1 \cdot 0, \wedge r$ & 120.35 & $1 \% \cdot 1.1$. \\
\hline & & Tomato & Cv1 & 123.18 & 125.62 & 155.10 & 155.40 \\
\hline & & pure & Cv2 & 100.16 & 102.36 & 131.39 & 124.11 \\
\hline & Iviean & Tomato & Cv1 & 137.69 & 140.85 & 140.44 & 161.61 \\
\hline & & + corn & Cv2 & 111.45 & 114.18 & 118.85 & 135.72 \\
\hline & & A-Cult & ars & 0.780 & 0.336 & 0.381 & 0.901 \\
\hline LS & D $0.05 \%$ & $\begin{array}{r}\text { B } \\
\text { Wastel }\end{array}$ & ater & 0.668 & 0.5490 & 0.406 & 1.235 \\
\hline & & $\begin{array}{r}\mathrm{C} \\
\text { Intercro }\end{array}$ & ping & 0.831 & 1.543 & 0.581 & 0.957 \\
\hline & & $\mathrm{AX}$ & & N.S & $\star \star *$ & ** & N.S \\
\hline & & $A X$ & & ** & ** & ** & ** \\
\hline & eraction & $A \times B$ & KC & $\star \star$ & ** & ** & N.S \\
\hline & & B X & & $\star *$ & ** & ** & N.S \\
\hline
\end{tabular}


Helali, M.N. et al.

Table (8): Dry weight of the two tomato genotypes (C) as affected by irrigation with waste water levels, (I) shading by an intercropping pattern (S) and their interactions throughout the experimental period of the two growing seasons 20072008 and 2008-2009.

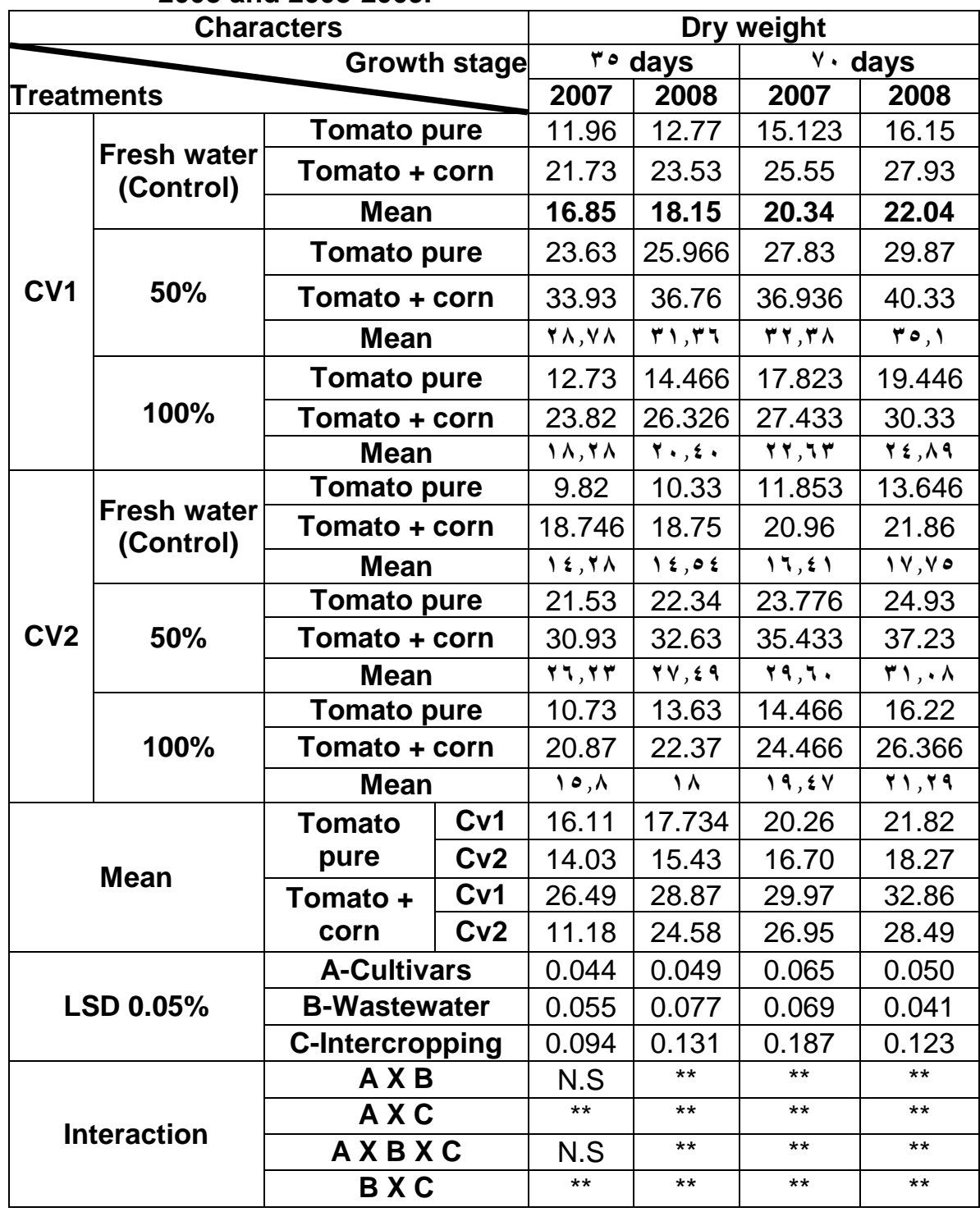


Table (9): Leaf area of the two tomato genotypes (C) as affected by irrigation with waste water levels, (I) shading by an intercropping pattern (S) and their interactions throughout the experimental period of the two growing seasons 20072008 and 2008-2009.

\begin{tabular}{|c|c|c|c|c|c|c|c|}
\hline \multicolumn{4}{|c|}{ Characters } & \multicolumn{4}{|c|}{ Leaf area } \\
\hline \multirow{2}{*}{\multicolumn{2}{|c|}{ Treatments }} & \multirow{2}{*}{\multicolumn{2}{|c|}{ Growth stage }} & \multicolumn{2}{|c|}{ ro days } & \multicolumn{2}{|c|}{$v \cdot$ days } \\
\hline & & & & 2007 & 2008 & 2007 & 2008 \\
\hline \multirow{9}{*}{ CV1 } & \multirow{3}{*}{$\begin{array}{l}\text { Fresh water } \\
\text { (Control) }\end{array}$} & \multicolumn{2}{|c|}{ Tomato pure } & 2801 & 2803 & 2905 & 2908 \\
\hline & & Tomato & orn & 2811 & 2813.67 & 2913.67 & 2917.33 \\
\hline & & Mea & & 2806 & 2808.34 & 2909.34 & 2912.67 \\
\hline & \multirow{3}{*}{$50 \%$} & \multicolumn{2}{|c|}{ Tomato pure } & 2817 & 2819.67 & 2923 & 2925 \\
\hline & & \multicolumn{2}{|c|}{ Tomato + corn } & 2828 & 2833 & 2925.67 & 2932 \\
\hline & & \multicolumn{2}{|c|}{ Mean } & YAYY,O & rAY,$r \leq$ & $Y Q Y \leq, r \leq$ & rqrA,० \\
\hline & & \multicolumn{2}{|c|}{ Tomato pure } & 2806 & 2806.33 & 2906 & 2912.67 \\
\hline & $100 \%$ & \multicolumn{2}{|c|}{ Tomato + corn } & 2822.33 & 2822.67 & 2927 & 2931.67 \\
\hline & & \multicolumn{2}{|c|}{ Mean } & $r \wedge I \leq, I V$ & $r \wedge 1 \leq, 0$ & $r 917,0$ & YqYY,IV \\
\hline \multirow{9}{*}{ CV2 } & \multirow{3}{*}{$\begin{array}{l}\text { Fresh water } \\
\text { (Control) }\end{array}$} & \multicolumn{2}{|c|}{ Tomato pure } & 2577 & 2583 & 2705 & 2707.67 \\
\hline & & \multicolumn{2}{|c|}{ Tomato + corn } & 2581 & 2585.67 & 2716.67 & 2717.33 \\
\hline & & \multicolumn{2}{|c|}{ Mean } & rova & $Y O \wedge \varepsilon, T \varepsilon$ & $Y \vee 1 \cdot, \Lambda \leq$ & YVIY,O \\
\hline & & \multicolumn{2}{|c|}{ Tomato pure } & 2584.33 & 2586.67 & 2721.67 & 2725 \\
\hline & $50 \%$ & \multicolumn{2}{|c|}{ Tomato + corn } & 2593.67 & 2596 & 2732.67 & 2738 \\
\hline & & \multicolumn{2}{|c|}{ Mean } & $r 0 \wedge q$ & $r 0 q 1, r \leq$ & YVYV,IV & YVMI,0 \\
\hline & \multirow{3}{*}{$100 \%$} & \multicolumn{2}{|c|}{ Tomato pure } & 2584.67 & 2584.67 & 2707.33 & 2711.67 \\
\hline & & \multicolumn{2}{|c|}{ Tomato + corn } & 2585.67 & 2587.67 & 2713 & 2717.33 \\
\hline & & \multicolumn{2}{|c|}{ Mean } & $r \otimes \wedge 0,1 V$ & $r \circ \wedge 7,1 V$ & $r V I \cdot, 1 V$ & $Y V I \leq, 0$ \\
\hline \multirow{4}{*}{\multicolumn{2}{|c|}{ Mean }} & Tomato & Cv1 & 2808 & 2809.67 & 2911.33 & 2915.22 \\
\hline & & pure & Cv2 & 2582 & 2584.78 & 2711.33 & 2714.78 \\
\hline & & Tomato + & Cv1 & 2820.44 & 2823.11 & 2922.11 & 2927 \\
\hline & & corn & Cv2 & 2586.78 & 2589.78 & 2720.78 & 2424.22 \\
\hline & & A-Culti & & 1.12 & $1, \cdot 7$ & 1.01 & 0.78 \\
\hline & D 0.05\% & B-Waste & ter & 1.05 & 1.86 & 1.47 & 2.08 \\
\hline & & C-Intercrc & ing & 0.48 & 2.43 & 1.87 & 2.04 \\
\hline & & $A X$ & & ** & ** & ** & ** \\
\hline & forentinn & $A X$ & & ** & ** & N.S & ** \\
\hline & teraction & AX B & & ** & ** & ** & ** \\
\hline & & B X & & * & N.S & ** & N.S \\
\hline
\end{tabular}


Helali, M.N. et al.

Table (10): Number of leaves of the two tomato genotypes (C) as affected by irrigation with waste water levels, (I) shading by an intercropping pattern (S) and their interactions throughout the experimental period of the two growing seasons 2007-2008 and 2008-2009.

\begin{tabular}{|c|c|c|c|c|c|c|c|}
\hline \multicolumn{4}{|c|}{ Characters } & \multicolumn{4}{|c|}{ Number of leaves } \\
\hline \multirow{2}{*}{\multicolumn{4}{|c|}{ Growth stage }} & \multicolumn{2}{|c|}{ ro days } & \multicolumn{2}{|c|}{$v \cdot$ days } \\
\hline & & & & 2007 & 2008 & 2007 & 2008 \\
\hline \multirow{9}{*}{ CV1 } & \multirow{3}{*}{$\begin{array}{c}\text { Fresh water } \\
\text { (Control) }\end{array}$} & \multicolumn{2}{|c|}{ Tomato pure } & 32.4 & 30.77 & 32.5 & 30.50 \\
\hline & & \multicolumn{2}{|c|}{ Tomato + corn } & 41.7 & 39.87 & 45.3 & 44.30 \\
\hline & & \multicolumn{2}{|c|}{ Mean } & 37.05 & 35.32 & 38.9 & 37.4 \\
\hline & \multirow{3}{*}{$50 \%$} & \multicolumn{2}{|c|}{ Tomato pure } & 43.73 & 40.80 & 48.83 & 46.67 \\
\hline & & \multicolumn{2}{|c|}{ Tomato + corn } & 54.6 & 51.73 & 58.53 & 56.63 \\
\hline & & \multicolumn{2}{|c|}{ Mean } & $\{9,1 V$ & $\varepsilon Y, Y V$ & or, Th & 01,70 \\
\hline & \multirow{3}{*}{$100 \%$} & \multicolumn{2}{|c|}{ Tomato pure } & 35.63 & 32.67 & 36.3 & 33.80 \\
\hline & & \multicolumn{2}{|c|}{ Tomato + corn } & 43.47 & 40.67 & 47.63 & 46.63 \\
\hline & & \multicolumn{2}{|c|}{ Mean } & $r 9,00$ & rq, TV & $\leqslant 1,9 V$ & $\varepsilon \cdot, Y Y$ \\
\hline \multirow{9}{*}{ CV2 } & \multirow{3}{*}{$\begin{array}{l}\text { Fresh water } \\
\text { (Control) }\end{array}$} & \multicolumn{2}{|c|}{ Tomato pure } & 27.73 & 25.60 & 30.27 & 29.73 \\
\hline & & \multicolumn{2}{|c|}{ Tomato + corn } & 41.70 & 30.70 & 45.73 & 43.60 \\
\hline & & \multicolumn{2}{|c|}{ Mean } & $r \varepsilon, V Y$ & $r \wedge, 10$ & $r \wedge$ & rq, TV \\
\hline & \multirow{3}{*}{$50 \%$} & \multicolumn{2}{|c|}{ Tomato pure } & 39.37 & 33.67 & 49.47 & 45.87 \\
\hline & & \multicolumn{2}{|c|}{ Tomato + corn } & 47.6 & 41.70 & 55.77 & 52.60 \\
\hline & & \multicolumn{2}{|c|}{ Mean } & $\leqslant r, \leqslant q$ & $r v, 79$ & $O Y, T Y$ & $\{q, Y \leqslant$ \\
\hline & \multirow{3}{*}{$100 \%$} & Tomato $\mathrm{p}$ & & 30.20 & 28.40 & 33.47 & 33.37 \\
\hline & & Tomato + & orn & 39.27 & 32.63 & 49.37 & 45.63 \\
\hline & & Mean & & $r \leq, V \leq$ & $r \cdot, O r$ & $\leqslant 1, \leqslant Y$ & $r q, 0$ \\
\hline & & Tomato nuro & Cv1 & 37.25 & 34.75 & 39.21 & 36.99 \\
\hline & Mean & Iomato pure & Cv2 & 32.43 & 29.22 & 37.74 & 36.32 \\
\hline & Iviean & Tomato + & Cv1 & 46.59 & 44.09 & 50.49 & 49.19 \\
\hline & & corn & Cv2 & 42.86 & 35.01 & 53.29 & 47.28 \\
\hline & & A-Cultive & & 0.091 & 0.106 & 0.111 & 0.095 \\
\hline & SD $0.05 \%$ & B-Wastew & ter & 0.157 & 0.164 & 0.179 & 0.126 \\
\hline & & C-Intercrop & ing & 0.041 & 0.104 & 0.228 & 0.0956 \\
\hline & & $A \times B$ & & $\star *$ & $\star \star$ & ** & $\star \star$ \\
\hline & & $A \times C$ & & ** & ** & ** & $\star *$ \\
\hline & teraction & A X B X & & ** & ** & ** & ** \\
\hline & & B X C & & ** & ** & ** & ** \\
\hline
\end{tabular}


Table (11): Number of days from transplanting to the beginning of flowering as affected by irrigation with waste water levels, (I) shading by an intercropping pattern (S) and their interactions throughout the experimental period of the two growing seasons 2007-2008 and 2008-2009.

\begin{tabular}{|c|c|c|c|c|c|}
\hline \multirow{2}{*}{\multicolumn{4}{|c|}{ Characters }} & \multirow{3}{*}{\multicolumn{2}{|c|}{$\begin{array}{c}\text { Number of days from } \\
\text { transplanting to the beginning of } \\
\text { flowering }\end{array}$}} \\
\hline & & & & & \\
\hline \multirow{2}{*}{\multicolumn{2}{|c|}{ Treatments }} & \multirow{2}{*}{\multicolumn{2}{|c|}{ Growth stage }} & & \\
\hline & & & & 2007 & 2008 \\
\hline \multirow{9}{*}{ CV1 } & \multirow{3}{*}{$\begin{array}{c}\text { Fresh water } \\
\text { (Control) }\end{array}$} & \multicolumn{2}{|c|}{ Tomato pure } & 45 & 40 \\
\hline & & \multicolumn{2}{|c|}{ Tomato + corn } & 40 & 35 \\
\hline & & \multicolumn{2}{|c|}{ Mean } & 42.5 & 37.5 \\
\hline & \multirow{3}{*}{$50 \%$} & \multicolumn{2}{|c|}{ Tomato pure } & 40 & 36 \\
\hline & & \multicolumn{2}{|c|}{ Tomato + corn } & 35 & 30 \\
\hline & & \multicolumn{2}{|c|}{ Mean } & $r v, 0$ & $r r$ \\
\hline & \multirow{3}{*}{$100 \%$} & \multicolumn{2}{|c|}{ Tomato pure } & 60 & 64 \\
\hline & & \multicolumn{2}{|c|}{ Tomato + corn } & 56 & 58 \\
\hline & & \multicolumn{2}{|c|}{ Mean } & $\Delta \wedge$ & 71 \\
\hline \multirow{9}{*}{ CV2 } & \multirow{3}{*}{$\begin{array}{l}\text { Fresh water } \\
\text { (Control) }\end{array}$} & \multicolumn{2}{|c|}{ Tomato pure } & 38 & 30 \\
\hline & & \multicolumn{2}{|c|}{ Tomato + corn } & 33 & 28 \\
\hline & & \multicolumn{2}{|c|}{ Mean } & $r 0,0$ & rq \\
\hline & \multirow{3}{*}{$50 \%$} & \multicolumn{2}{|c|}{ Tomato pure } & 31 & 26 \\
\hline & & \multicolumn{2}{|c|}{ Tomato + corn } & 28 & 24 \\
\hline & & \multicolumn{2}{|c|}{ Mean } & $r 9,0$ & ro \\
\hline & \multirow{3}{*}{$100 \%$} & \multirow{2}{*}{\multicolumn{2}{|c|}{$\begin{array}{l}\text { Tomato pure } \\
\text { Tomato + corn }\end{array}$}} & 26 & 15 \\
\hline & & & & 23 & 15 \\
\hline & & \multicolumn{2}{|c|}{ Mean } & $r \leqslant, 0$ & 10 \\
\hline & & Tomato & Cv1 & 48.33 & 46.67 \\
\hline & Mean & pure & Cv2 & 31.67 & 23.67 \\
\hline & Iviean & Tomato + & Cv1 & 43.67 & 41 \\
\hline & & corn & Cv2 & 28 & 22.33 \\
\hline & & A-Culti & & 0.726 & 0.419 \\
\hline & SD $0.05 \%$ & B-Waste & ter & 0.768 & 0.941 \\
\hline & & C-Intercro & jing & 0.828 & 2.484 \\
\hline & & $\mathbf{A X}$ & & ${ }^{* *}$ & $\star *$ \\
\hline & & $\mathbf{A X}$ & & N.S & $\star \star *$ \\
\hline & teraction & AX B & & N.S & * \\
\hline & & B X & & N.S & N.S \\
\hline
\end{tabular}

\section{REFERENCES}

Bakry, M.O. (1973). Carbohydrate and nitrogen metabolism of pea plants in relation to photo-thermoperiodism. M.Sc. Thesis, Fac. of Agric. Cairo Univ., Egypt.

Beardsell, M.F. and D. Cohen (1975). Relationships between leaf water status, abscisic acid levels and stomatal resistance in maize and sorghum. Plant Physiol., 56: 207-212.

Eisa, G.S. (1998). Botanical studies on sesame plant. M. Sc. Thesis, Faculty of Agric. Zagazig Univ., Egypt. 
Helali, M.N. et al.

El-Dodo, M.K. (1976). Some physiological studies on sesame plant (Sesamum indicum, L.) in relation to its water requirements. M. Sc. Thesis, Fac., Agric. Cairo Univ. Egypt.

El-Shafey, Y.H.; S.M. Salem; O.M. El-Shihy: A.M. Ghallab and Hanaa F.Y. Mohamed (2003). Effect of gamma rays, abscisic acid and putrescine on production of wheat plants more tolerant to salinity: B- in vitro callus induction, plant regeneration, and grains production under saline conditions. J. Agric. Sci. Mans. Univ., 28(5): 3551-3570.

Ghallab, A.M.; and A.E. El-Ghadban (2003). Reinforcing salt tolerance of Mrijoram plants by foliar application of putrescine. J. Agric. Sci., 28(4): 2651-2669, Mansoura Egypt.

Ghallab, A.M.; and A.E. El-Ghadban (2004). Physiological response of Marjoram plants to biofertilizer and organic fertilization. J. Agric. Sci., 29(4): 1743-1759, Mans. Univ., Egypt.

Ghallab, A.M.; and M.R.A. Nesiem (1999). Effect of Foliar application of titanium on growth, chemical composition and productivity of soybean and wheat plants growing under different levels of NPK fertilization $\mathrm{J}$. Agric. Sci. Mans., Univ., 24(2): 605-623.

Goma, H.M. (1966). Effect of shading and training an wires on the growth, yield and fruit quality of tomato plants. Ph.D thesis Fac. Of Agric. AinShams Univ., Egypt.

Gomez, K. A. and A.A. Gomez (1984). Statistical Procedures for Agriculture Research. $2^{\text {nd }}$ Ed. John Wiley and Sons. pp. 680.

Hanafy Ahmed, S.M.; S.M. Mandour; A.M. Ghallab and G.A. Diab (2002). Effect of nitrogen, potassium and micronutrients fertilization on the growth, yield and chemical composition of some sorghum cultivars growing under saline and sandy soil conditions. $2^{\text {nd }}$ Congress of Recent Technologies in Agric., Giza, 28-30 Oct. IV: 876-900.

Hatung, W. (2004). Plant response to stress: Abscisis acid fluxes. Marcel Dekker Inc., New York. pp. 540-690.

Hayward, W.E. and E.M. Long (1943). Some effects of sodium salts on the growth of the tomato. Plant Physiol., 18(4): 556-569.

Helaly, M. N.; Fouda, R.A. and Ramadan, E.A. (2009). Microbiological and anatomical studies on potatoes as affected by bio and mineral fertilizers J. Agric. Sci. Mans. Univ., 34(1): 279-308.

Helaly, M.N.M. A.M. Salama and A.A. Arafa (1984a). Effects of salinity on growth, mineral constituents, water fraction and endogenous growth substances in horse been plants. J. Agric. Sci., 9: 251-264, Mansoura Univ., Egypt.

Helaly, M.N.M.; S.Z.M. El-Basyouni and A.A. Arafa (1985a). Physiological studies on salt tolerance in chamomile plant. $2^{\text {nd }}$ Conf. Agric. Botany Sci., 21-24 Sept., 1:125-148, Mansoura Univ., Egypt.

Helaly, M.N.M.; S.Z.M. El-Basyouni and A.M. Salama (1985b). Morphological and physiological studies on petunia plants $2^{\text {nd }}$ Conf. Agric., Bot. Sci. 21-24 Sept. Fac. of Agric. Mansoura Univ. Egypt. 
Helaly, M.N.M.; Mohammed, Z. M. and Nofal, I.E. (2009). Comparative botanical studies on two newly tomato genotypes as affected by wastewater and shading. II. Endogenous photohormones J. Agric., Sci. Mansoura Univ. Egypt In press.

Jackson, M.L.(1973). Soil Chemical analysis. Prentice-Hall of India private. New Delhi, pp. 144-197.

Jeffrey, W.D. (1987). Soil Plant Relationships, An Ecological Approch Groom Helm Ltd., Provident House, Bunel Row Backenham, Kenl BR3 IAT.

Johanson, R.E. (1967). Comparison of methods for estimating cotton leaf area. Agron. Jour. 59:493-494.

Salisbury, F.B. and C.W. Ross, (1992). Environmental physiology. In : plant physiology, $4^{\text {th }}$ ed, p. 449-500. Wadsworth pub. Company, Beimor CA, USA.

$$
\begin{aligned}
& \text { دراسة نباتيه مقارنة لبعض التراكيب الو راثية في الطماطم }
\end{aligned}
$$

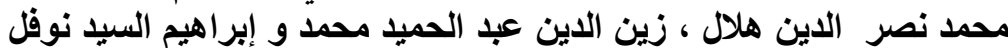

$$
\begin{aligned}
& \text { قسم النبات الزراعي ـكلية الزراعة ـ جامعة المنصورة - مصر }
\end{aligned}
$$

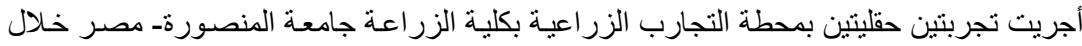

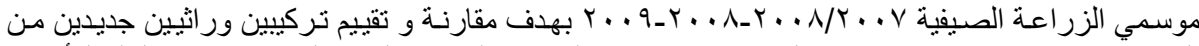

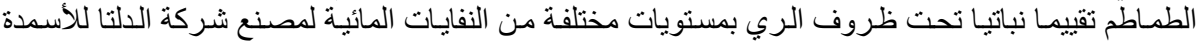

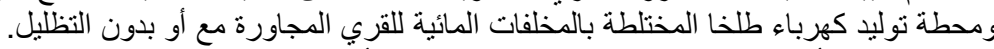

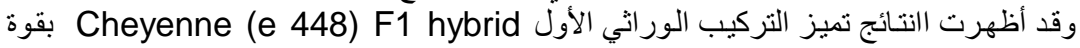

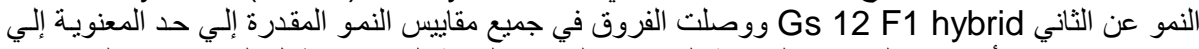

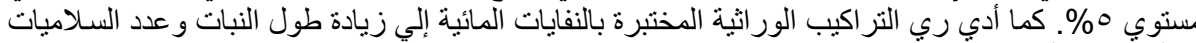

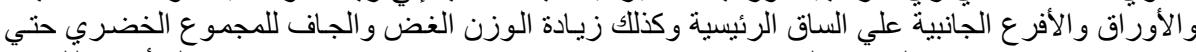

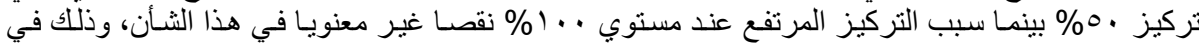

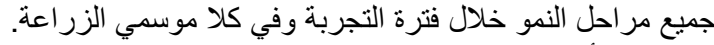

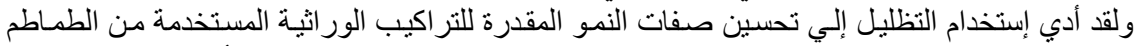

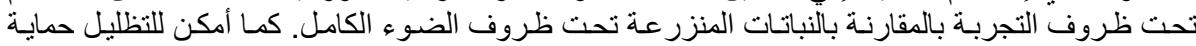

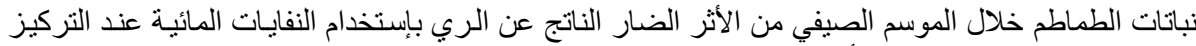

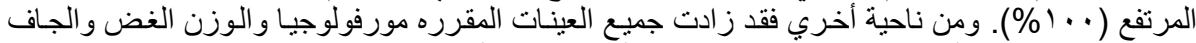

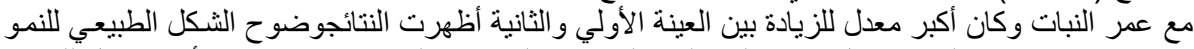

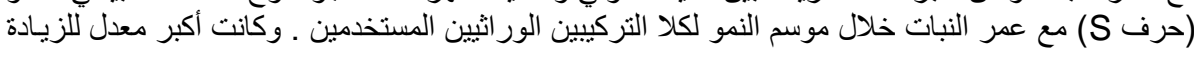

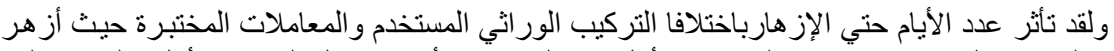

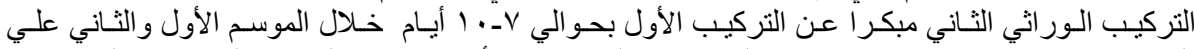

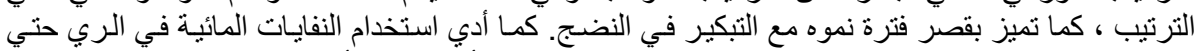

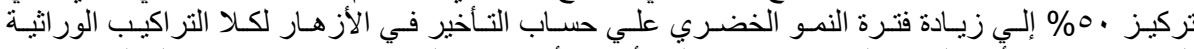

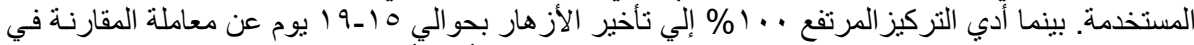

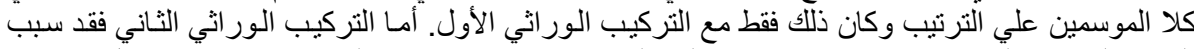

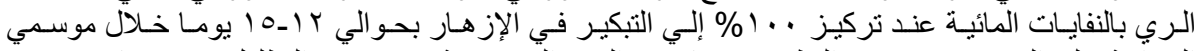

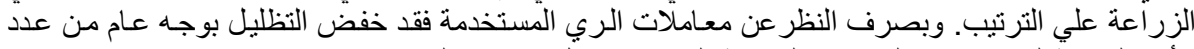

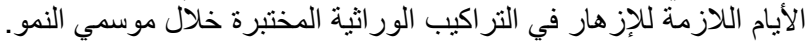

